\title{
Microbiological Properties of Soils as Affected by Long Term Zero Tillage: A Review
}

\author{
Mamta Phogat*, Rita Dahiya, P. S. Sangwan and M. Santhosh Kumar \\ Chaudhary Charan Singh Haryana Agricultural University, Hisar, India \\ *Corresponding author
}

Keywords

Zero Tillage,

Conventional

tillage, Microbial

biomass carbon,

Sustainable

production

Article Info

Accepted:

04 October 2020

Available Online:

10 November 2020

\begin{abstract}
A B S T R A C T
The use of resource management technologies such as zero tillage, which can affect the soil properties, can restore soil health that is degrading at a rapid pace due to intensive agriculture, inefficient and imbalanced use of fertilisers, high-yielding crops, the use of heavy machinery, excessive tillage, etc. The health of the soil can be measured by the capacity of microorganisms that can act as early warning signals. To improve soil quality, zero tillage is recommended globally and has significant effects on soil microbial communities. We do, however, know much less about biological influences than about the physical and chemical properties of the soil. Tillage helps to establish a favourable soil condition for plant growth, but it modifies the soil ecosystem and microbial communities responsible for organic matter decomposition and nutrient cycling on a long-term basis. The intensity of tillage has different effects on the biological properties of soils through changes in soil habitat, affecting soil porosity, soil water quality, distribution of residues and availability of substrates, etc. Zero tillage can enhance the structure of the soil, soil temperature and water holding capacity, thereby improving the microbial properties of the soil. By improving soil structure, nutrient status, water holding capacity and, eventually, all soil microbial communities and their activities, this improves soil quality. Long-term zero tillage practises can therefore improve the soil's microbial properties.
\end{abstract}

\section{Introduction}

A better understanding of the effects of zero tillage on microbial activity and abundance is necessary if nutrient availability, soil structure, and water availability are to be balanced. There are various global issues calling for reform. Soil erosion and degradation, biodiversity loss and pollution of adjacent natural systems all call into question current practises in agricultural management. In order to satisfy sustainability criteria, there is a particular need to build alternative systems that take into account the surrounding environment, beyond individual technologies. The world population is expected to be about 9.8 billion by 2050 and 37 percent of them will live in China and India (UN, 2017), requiring an estimated 59-98 percent increase in food demand (Valin et al., 2014), putting more strain on natural resources. The world is facing a population boom today and there is an immediate need to sustainably improve agricultural productivity and overall food 
production without sacrificing the atmosphere and natural resources. Technologies introduced in the country during the 1966-67 green revolution led to food security, intensive cropping, inadequate and imbalanced fertiliser usage, high yielding crop varieties, heavy machinery usage, excess tillage, etc., resulting in soil health and deterioration of quality. Five of the top ten problems facing humanity (i.e. food, water, the environment, energy and poverty) have been directly related to soil health and quality for the next 50 years. The introduction of conservation agriculture therefore involves a growing concern for food security through best practises in soil management. Conservation agriculture is a resource-saving mechanism for producing agricultural crops that aims to achieve equal benefits along with high and sustained production levels in this era of climate change while protecting the environment at the same time (FAO, 2010). Zero tillage is the most significant aspect of conservation farming. The best way to challenge all these problems is zero tillage. Zero tillage refers to soil management systems that result in crop residues covering at least 30 percent of the soil surface, one of the aspects of conservation agriculture (Jarecki and Lal, 2003). Zero tillage (ZT) is an important part of conservation agriculture that, compared to conventional tillage (CT), reduces soil disruption, amplifies physical, chemical and biological properties of the soil, retains soil and water, and reduces the total cost of production (Baker et al., 2007). Soil edaphic variables as well as the biological properties of the soil are influenced by tillage practises. In fact, some of the biological characteristics can be used as useful soil quality and health indicators (Carbonetto et al., 2014). The impact of soil laying on the structure and functions of soil microbial communities has been documented in a wide body of literature (Degrune et al., 2016; Srour et al., 2017c). Under various tillage regimes and crop residue management methods, varying soil physical and chemical factors create distinct environments for microbes and result in changes in the composition of the soil microbiome (Murphy et al., 2016). Edaphic variables such as temperature, soil moisture, $\mathrm{pH}$, oxygen, nutrient availability, organic matter, soil texture, and host plants also influence the soil microbial population (Leff et al., 2015). To enrich the soil microbial culture, zero tillage practises with crop residue retention have been shown. This can be due in part to the well-documented role that soil microbes play in the cycling of soil nutrients (He et al., 2007). In addition, zero tillage systems have been found to be associated with a greater diversity of bacterial and fungal species compared to traditional tillage (CT) (Helgason et al., 2010). Fungal and bacterial species commonly known as decomposers are typically found to be prevalent in soils with zero tillage (Nicolardot et al., 2007). Likewise, under conservation labour, arbuscular mycorrhizal fungi are typically more abundant (Sale et al., 2015). Natural biofertilizers that supply the host with water and nutrients and protect it from root pathogens in exchange for photosynthetic products are also considered to be arbuscular mycorrhizal fungi. Hobbs et al.. Via improving soil structure, soil water holding capacity, nutrient cycling and improving soil biological activities, (2008) reported improvements in soil quality. In addition, soil microbial biomass and soil nutrient cyclingrelated enzymatic activities have been documented to enhance conservation tillage practises (Murphy et al., 2016). A successful assessment of soil quality and fertility has been considered to compensate for the concentration and availability of nutrients in the soil from mineralization (Polyakov and Lal, 2004; Olson et al., 2005). The dynamics of $\mathrm{C}$ and $\mathrm{N}$ accumulation in soils not only boost soil physical parameters, conserve soil moisture, and minimise erosion, but also drive 
microbial activity and nutrient cycling, given the close relationship between soil organic carbon, total nitrogen and microbial metabolic activities (Manna et al., 2007). Study plays a vital role in dealing with the never-ending problems associated with human life. Through more and more experimenting, a greater understanding of the real world is achieved. Owing to the accumulated nature of science, hundreds or thousands of studies discuss the same subject from several perspectives (Shoemaker et al., 2003). In addition, outcomes are often highly complex, and extremely difficult to comprehend, leading to widely scattered processes in different parts of the globe. Narrative reviews will detail the exceedingly varied scientific results to create a description. A study cumulates and summarises all the available literature on a given topic in order to analyse the outcome quantitatively by relevant primary studies and the source of variance between these results (Olkin, 1995; Gurevitchet et al., 2018).

\section{Impact of zero tillage on soil microbial properties}

Due to tilling activities, changes in soil properties result in changes in its biological life. There are numerous indices that measure soil biological activities; both micro flora and micro fauna are equally concerned. Tillage practises affect soil aeration, which directly affects the growth of the aerobic population responsible for organic matter mineralization, so intensive tillage contributes to a reduction in soil humus content. Soil fauna activities are important in the formation and aggregation of organo-mineral complexes and thus the enhancement and diversification of soil fauna helps to improve soil structure. The strength of soil tillage greatly affects populations of earthworms and their operations. Decomposition and incorporation of straw are aided by earthworms. Increased activity of earthworms was also documented by Tebrugge and during (1999) and Rasmussen (1999) in no-till treatments.

\section{Microbial biomass carbon and nitrogen}

Tillage practises interrupt soil aggregates that expose organic matter to microbial degradation, eventually oxidising $\mathrm{CO}_{2}$ to organic matter. Balota et al., (2004) stated that, as opposed to traditional tillage, zero tillage significantly increased the soil microbial biomass $\mathrm{C}$ (MBC). Other zero tillage systems increased total $\mathrm{C}$ by 45 percent over traditional tillage, microbial biomass by 83 percent and $\mathrm{MBC}$ : total $\mathrm{C}$ ratio by 23 percent at the upper $5 \mathrm{~cm}$ depth. With ZT up to $0-20 \mathrm{~cm}$ deep, the $\mathrm{C}$ and $\mathrm{N}$ mineralization improved to 74 percent. A relatively small element of the SOM is the MBC. It only accounts for 1-3 percent of total soil C. A source (mineralization) or a sink (immobilisation) of labile nutrients (Hu et al., 1997) with a turnover period from days to years (Tedla et al., 2004) is also considered labile C by the MBC. Guo et al., (2015) reported that, compared to conventional tillage treatments, zero tillage treatments increased $\mathrm{MBC}$ by 11.5 percent, and 20 percent in $>0.25 \mathrm{~mm}$ aggregate and $<0.25$ $\mathrm{mm}$ aggregate in $0-5 \mathrm{~cm}$ soil layer, respectively. As indicated by enhanced microbial biomass and activity, increased $\mathrm{C}$ storage can also boost biological soil quality (Sainju et al., 2007). In soil fertility considerations, microbial biomass, a small (15 percent by weight) but active fraction of soil organic matter, is of particular concern because it is more sensitive to management activities than organic matter in bulk (Janzen et al., 1992). In contrast to being homogeneous in the $0-15-\mathrm{cm}$ layer under plough tillage (Alvarez and Steinbach, 2009), microbial biomass $\mathrm{C}(\mathrm{MBC})$ is also stratified under zero tillage. This significant increase in microbial biomass carbon and nitrogen under 
zero tillage might be due to more crop residues retention and undisturbed conditions which enhances organic matter and more organic matter increases microbial activity for its decomposition, consequently more microbial biomass carbon. With the rise in profile moisture under zero tillage, microbial biomass carbon and nitrogen also increased as high moisture provides favourable conditions for microbial activity (Kandeler et al., (2006)).

\section{Microbial count}

Phospholipid fatty acid (PLFA) analysis and automated ribosomal intergenic spacer analysis (ARISA) assessed soil microbial group structure varied by tillage practise. Compared to the drier and warmer soils under more extensive tillage, the soil micro climate in zero tilled soils is usually cooler and moister (Martens, 2001). Under zero tillage soils, some researchers recorded greater microbial abundance with a more favourable microclimate compared to soils under traditional tillage (Das et al., 2014). This large increase in the zero tillage microbial population was attributed to high soil organic carbon, which gave the microbes better food availability (Govaerts et al., 2008). Crop residues under zero tillage provide substrate for the microbial growth. More substrate was supplied by crop residues under zero tillage and higher moisture also provided favourable conditions for the microbes to proliferate. Ghimire et al., (2014), Govaerts et al., (2008) and Choudhary et al., (2018) have noted the same findings.

\section{Root density}

In addition to sustaining the plant system, plant roots are regarded as a critical component with a significant function in providing the plant system with nutrients and water (Spedding et al., 2004). In addition, the growth of the above-ground shoot and grain yield depends greatly on the growth of the under-ground root (Jeschke et al., 1997). Plant potential for water and nutrient uptake is entirely determined by the distribution and production of underground roots (Fageria, 2005). There was more root system contribution to corn yield than shoot contribution (Hammer et al., 2009). The combined effect of physico-chemical properties of the soil and genetic build-up of the plant is typically determined by root growth characteristics and exhibits high plasticity in different growing environments (Lynch, 2011). A plant's ability to obtain water along with essential nutrients from soil layers depends on the growth and extension of the root. Mosaddeghi et al., (2009) stated that due to modifications in the root growth environment, the most significant effect of tillage could be on the root function and production. In both surface and subsurface soil layers, soil compaction can seriously limit root growth, preventing the root system from taking up water and nutrients from deeper layers. Soil compactions limit the penetration of the root (Batey, 2009; Kadžienž et al., 2011), impede the proliferation of the root (Tracy et al., 2013), and reduce the elongation of the root in the soil profile (Guaman et al., 2016). Due to greater water and nutrient availability, root proliferation was maximal in the surface soil layer (Lynch, 2011). The existence of a compact subsurface layer reduced the plant's ability to extract water and nutrients from deeper layers and increased the risk of leaching nutrients in ground water, particularly NO3 (Thorup-Kristensen, 2011). Clark et al., (2008) and Bengough et al., (2011) have reported reduced yield capacity and restricted root growth under the compacted subsoil layer. Conventional tillage creates a fine seed bed and, particularly in the surface soil layer, encourages root growth. However, due to long-term conventional tillage, compacted subsurface soil layer 
formation can negate the beneficial effect of conventional tillage. In stubble seeding of maize than rotary tillage in a thick loam soil, Bian et al., (2016) observed lower root length density $(7,10,12$ percent at 0-20, 20-40, 40$60 \mathrm{~cm}$, respectively) and lower root average diameter ( 8 percent at $0-20 \mathrm{~cm}, 24$ percent at $20-40 \mathrm{~cm}$, and 14 percent at $40-60 \mathrm{~cm}$ ). Similar findings were published by other researchers (Guan et al., 2014). However, contrasting findings are available and deep and better root production was recorded due to higher soil moisture retention in zero tillage (Lampurlanés et al., 2001). Due to improved physical conditions of the soil, Chen and Weil (2011) observed greater root growth and yield under the zero tillage scheme. Experimental results showed that the density of root mass decreased with the depth of the soil. In the mungbean-wheat cropping method, high crop residues under zero tillage are due to improved soil structure and the balance of macro and micro porosity may have resulted in high density of root mass. Costa et al., (2010) and Dusserre et al., (2012) have also found greater root density.

In conclusion the number of food-insecure individuals will increase because of the unparalleled increase in the world population and rapid economic growth. Furthermore, the per capita cropland area is also decreasing due to increased popularity, soil erosion, urbanisation, and other competitive uses. The Green Revolution of the 1960s improved food production, but due to industrial agriculture, heavy field machinery, excessive use of irrigation, and indiscriminate use of fertilisers and pesticides, there were strong climate confrontational effects, including loss of SOC stock, increased chances of soil erosion and depletion of salinization, and deterioration of soil biological properties Therefore, the strategic goal is to balance the need for food production with the need for soil regeneration and the reduction of the environmental footprint of agro-ecosystems, and this can be accomplished by using sustainable methods such as zero tillage. The plan is to improve the quality of the soil by restoring SOC stocks, improving the productivity of inputs for use, reducing the yield gap and implementing sustainable intensification systems for agro-ecosystems. The aim is to generate more from less ground, less water usage, less input of fertiliser and pesticide, and less use of electricity. The much needed paradigm change would also include identifying and implementing successful policies in order to turn empirical knowledge into reality. It is possible to extend its usage by developing site-specific packages and educating the farming community and the general public about the merits of zero tillage and soil resource stewardship. One of the best solutions with the potential to optimise all the physical resources of the land, conserve soil and water, and maintain productivity is zero tillage, properly implemented. Finally, we concluded in a nut shell that long-term zero tillage practises could boost the biological properties of the soil and conserve soil resources for sustainable farming.

\section{References}

Alvarez, R. and Steinbach, H. S. (2009). A review of the effects of tillage systems on some soil physical properties, water content, nitrate availability and crops yield in the Argentine Pampas. Soil \& Tillage Research, 104: 1-15.

Baker J M, Ochsner T E, Venterea R E and Griffis $\mathrm{T}$ J (2007) Tillage and soil carbon sequestration. What do we really know? Agric Ecosyst Environ 118: 1-5.

Balota, E.L., Colozzi, A., Andrade, D.S. and Dicky, R.P. (2004). Long-term tillage and crop rotation effects on microbial biomass and $\mathrm{C}$ and $\mathrm{N}$ mineralization in a Brazilian oxisol. Soil \& Tillage Research.77: 137-145.

Batey, T. (2009).Soil compaction and soil management-a review. Soil Use and Management, 25: 335-345.

Bengough, A. G., McKenzie, B. M., Hallett, P. D. 
and Valentine, T. A. (2011). Root elongation, water stress, and mechanical impedance: a review of limiting stresses and beneficial root tip traits. Journal of Experimental Botany, 62: 59-68.

Bian, D., Jia, G., Cai, L., Ma, Z., Eneji, A. E. and Cui, Y. (2016). Effects of tillage practices on root characteristics and root lodging resistance of maize. Field Crops Research, 185: 89-96.

Carbonetto, B., Rascovan, N., Alvarez, R., Mentaberry, A., and Vazquez, M. P. (2014). Structure, composition and metagenomic profile of soil microbiomes associated to agricultural land use and tillage systems in Argentine Pampas. PLoS One 9:e99949. doi: 10.1371/journal.pone.0099949.

Chen, G. and Weil, R. R. (2011). Root growth and yield of maize as affected by soil compaction and cover crops. Soil \& Tillage Research, 117: 17-27.

Choudhary, M., Datta, A., Jat, H. S., Yadav, A. K., Gathala, M. K., Sapkota, T. B., Das, A. K., Sharma, P. C., Jat, M. L., Singh, R. and Ladha, J. K. (2018). Changes in soil biology under conservation agriculture based sustainable intensification of cereal systems in Indo-Gangetic Plains. Geoderma, 313: 193-204.

Clark, L. J., Price, A. H., Steele, K. A. and Whalley, W. R. (2008).Evidence from nearisogenic lines that root penetration increases with root diameter and bending stiffness in rice. Functional Plant Biology, 35: 11631171.

Costa, S. E. V. G. A., Souza, E. D., Anghinoni, I., Flores, J. P. C., Vieira, F. C. B., Martins, A. P. and Ferreira, E. V. O. (2010). Patterns in phosphorus and corn root distribution and yield in long-term tillage systems with fertilizer application. Soil \& Tillage Research, 109: 41-49.

Degrune, F., Theodorakopoulos, N., Dufrene, M., Colinet, G., Bodson, B., Hiel, M. P., et al., (2016). No favorable effect of reduced tillage on microbial community diversity in a silty loam soil (Belgium). Agricult. Ecosyst Environ. 224, 12-21. doi: 10.1016/j.agee.2016.03.017.

Dusserre, J., Chopart, J. L., Douzet, J. M., Rakotoarisoa, J. and Scopel, E
(2012).Upland rice production under conservation agriculture cropping systems in cold conditions of tropical highlands. Field Crops Research, 138: 33-41.

Fageria, N. K. (2005). Influence of dry matter and length of roots on growth of five field crops at varying soil zinc and copper levels. Journal of Plant Nutrition, 27: 1517-1523.

FAO (2010). What is conservation agriculture; FAO CA-website http://www.fao.org/ag/ca/1a.html. Accessed on $13 / 08 / 2019$.

Ghimire, R., Norton, J.B., Stahl, P.D. and Norton, U. (2014). Soil microbial substrate properties and microbial community responses under irrigated organic and reduced-tillage crop and forage production systems. PLoS One, 9(8) e103901.

Govaerts, B., Sayre, K.D., Crossa, J., Lichter, K., Troch, V., Vanherck, K., Corte, P.D. and Deckers, J. (2008). Long term consequences of tillage, residue management and crop rotation on selected microflora group in the subtropical highland. Applied Soil Ecology, 38: 197-210.

Guaman, V., Båth, B., Hagman, J., Gunnarsson, A. and Persson, P. (2016). Short time effects of biological and inter-row subsoiling on yield of potatoes grown on a loamy sand, and on soil penetration resistance, root growth and nitrogen uptake. European Journal of Agronomy, 80: 55-65.

Guan, D., Al-Kaisi, M. M., Zhang, Y., Duan, L., Tan, W., Zhang, M. and Li, Z. (2014). Tillage practices affect biomass and grain yield through regulating root growth, rootbleeding sap and nutrients uptake in summer maize. Field Crops Research, 157: 89-97.

Guo, L. J., Zhang, Z. S., Wang, D. D., Li, C. F. and Cao, C. G. (2015).Effects of shortterm conservation management practices on soil organic carbon fractions and microbial community composition under a rice-wheat rotation system. Biology and Fertility of Soils, 51: 65-75.

Gurevitch, J., Koricheva, J., Nakagawa, S. and Stewart, G. (2018). Meta-analysis and the science of research synthesis. Nature, 555, 175-182.

Hammer, G. L., Dong, Z., McLean, G., Doherty, A., Messina, C., Schussler, J., Zinselmeier, 
C., Paszkiewicz, S. and Cooper, M. (2009). Can changes in canopy and/or root system architecture explain historical maize yield trends in the US corn belt? Crop Science, 49: 299-312.

Helgason, B. L., Walley, F. L., and Germida, J. J. (2010). Long-term no-till management affects microbial biomass but not community composition in Canadian prairie agroecosytems. Soil Biol. Biochem. 42, 2192-2202. doi: 10. 1016/j.soilbio.2010.08.015.

Hobbs, P. R., Sayre, K. and Gupta, R. (2008). The role of conservation agriculture in sustainable agriculture. Philosophical Transactions of the Royal Society of London B: Biological Sciences, 363: 543-555.

$\mathrm{Hu}$, S.; Grunwald, N.J.; vanBruggen, A.H.C. et al., (1997). Short-term effects of cover crop incorporation on soil carbon pools and nitrogen availability. Soil Sci. Soc. Am. J. 61:901-911.

Janzen, H. H., Campbell, C. A., Brandt, S. A., Lafond, G. P. and Smith, L. T. (1992). Lightfraction organic matter in soils from longterm crop rotations. Soil Science Society of America Journal, 56: 1799-1806.

Jarecki, M.K. and Lal, R. (2003).Crop management for soil carbon sequestration.Critical Reviews in Plant Sciences, 22: 471-502.

Jeschke, W. D., Baig, A. and Hilpert, A. (1997). Sink-stimulated photosynthesis, increased transpiration and increased demanddependent stimulation of nitrate uptake: nitrogen and carbon relations in the parasitic association Cuscutareflexa-Coleus blumei. Journal of Experimental Botany, 48: 915925.

Kadžienė, G., Munkholm, L. J. and Mutegi, J. K. (2011). Root growth conditions in the topsoil as affected by tillage intensity. Geoderma, 166: 66-73.

Kandeler, E., Mosier, A.R., Morgan, J.A., Milchunas, D.G., King, J.A., Rudolph, S. and Tscherko, D.(2006). Response of soil microbial biomass and enzyme activities to the transient elevation of carbon dioxide in semi-arid grassland. Soil Biology and Biochemistry.38:2448-2460.

Lampurlanés, J., Angás, P. and Cantero-Martınez,
C. (2001). Root growth, soil water content and yield of barley under different tillage systems on two soils in semiarid conditions. Field Crops Research, 69: 27-40.

Leff, J. W., Jones, S. E., Prober, S. M., Barberan, A., Borer, E. T., Firn, J. L., et al., (2015). Consistent responses of soil microbial communities to elevated nutrient inputs in grasslands across the globe. Proc. Natl. Acad. Sci. U.S.A. 112, 10967-10972. doi: 10.1073/pnas. 1508382112 .

Lynch, J. P. (2011). Root phenes for enhanced soil exploration and phosphorus acquisition: tools for future crops. Plant Physiology, 156: 10411049.

Manna, M. C., Swarup, A., Wanjari, R. H., Mishra, B., and Shahi, D. K. (2007).Longterm fertilization, manure and liming effects on soil organic matter and crop yields. Soil Tillage Res. 94, 397-409. doi: 10.1016/j.still.2006. 08.013.

Martens, D. A. (2001).Nitrogen cycling under different soil management systems. Advances in Agronomy, 70:143-193.

Mosaddeghi, M. R., Mahboubi, A. A. and Safadoust, A. (2009). Short-term effects of tillage and manure on some soil physical properties and maize root growth in a sandy loam soil in western Iran. Soil \& Tillage Research, 104:173-179.

Murphy, R. P., Montes-Molina, J. A., Govaerts, B., Six, J., Van Kessel, C., and Fonte, S. J. (2016). Crop residue retention enhances soil properties and nitrogen cycling in smallholder maize systems of Chiapas. Mexico. Appl. Soil Ecol. 103, 110-116. doi: 10.1016/j.apsoil.2016.03.014.

Nicolardot, B., Bouziri, L., Bastian, F., and Ranjard, L. (2007). A microcosm experiment to evaluate the influence of location and quality of plant residues on residue decomposition and genetic structure of soil microbial communities. Soil Biol. Biochem. 39, 1631-1644. doi: 10.1016/j.soilbio.2007. 01.012.

Olkin, I. (1995). Keynote addresses. Meta-analysis: Reconciling the results of independent studies. Statistics in Medicine, 14, 457-472.

Olson, K. R., Lang, J. M., and Ebelhar, S. A. (2005). Soil organic carbon changes after 12 
years of no-tillage and tillage of Grantsburg soils in southern Illinois. Soil Tillage Res. 81, 217-225. doi: 10.1016/j.still.2004.09.009

Polyakov, V. O., and Lal, R. (2004).Soil erosion and carbon dynamics under simulated rainfall. Soil Sci. 169, 590-599. doi: 10.1097/01.ss.0000138414.84427. 40

Rasmussen, K. J. (1999). Impact of ploughless soil tillage on yield and soil quality: a Scandinavian review. Soil \& Tillage Research, 53: 3-14.

Sainju, U.M., Lenssen, A., Caesar-Tonthat, T. and Waddell, J. (2007). Dryland plant biomass and soil carbon and nitrogen fractions on transient land as influenced by tillage and crop rotation. Soil \&Tillage Research, 93:452-461.

Sale, V., Aguilera, P., Laczko, E., Mader, P., Berner, A., Zihlmann, U., et al., (2015). Impact of conservation tillage and organic farming on the diversity of arbuscular mycorrhizal fungi. Soil Biol. Biochem. 84, 38-52. doi: 10.1016/ j.soilbio.2015.02.005.

Shoemaker, P. J., Tankard Jr, J. W. and Lasorsa, D. L. (2003). How to build social science theories. Sage publications.

Sidhu, D. and Duiker, S. W. (2006).Soil compaction in conservation tillage. Agronomy Journal, 98: 1257-1264.

Spedding, T. A., Hamel, C., Mehuys, G. R. and Madramootoo, C. A. (2004). Soil microbial dynamics in maize-growing soil under different tillage and residue management systems. Soil Biology \& Biochemistry, 36: 499-512.

Srour, A. Y., Hackman, J., Cook, R., Bond, J. P., and Fakhoury, A. M. (2017c). "Impact of long-term tillage and fertility treatments on soil microbial communities," in 2017 APS Annual Meeting, Saint Paul, MI: APSNET.

Tebrugge, F. and During, A.R. (1999). Reducing tillage intensity - a review of results from a long-term study in Germany. Soil \&Tillage Research, 53:15-28.

Tedla, A.B.; Su, B.; Luo, Y. and Wallace, L.L. (2004). Carbon and nitrogen dynamics in experimentally warmed and clipped tallgrass prairie soil. Ecol. Soc. Am. Ann. Meeting Abstracts, 89:501.

Thorup-Kristensen, K. (2011). Strick Danish regulations on nitrogen use and how understanding vegetable crop root growth may help us improve nitrogen use efficiency. In: IV Jornadas Fertilización SECH. Sociedad Española de Ciencias. Hortícolas, Castelldefels (Barcelona), Spain. pp. 4-7.

Tracy, S. R., Black, C. R., Roberts, J. A. and Mooney, S. J. (2013).Exploring the interacting effect of soil texture and bulk density on root system development in tomato (Solanum lycopersicum L.). Environmental and Experimental Botany, 91: 38-47.

United Nations. (2017). World Population Prospects: The 2017 Revision. United Nations, New York.

Valin, H., Sands, R.D., van der Mensbrugghe, D., Nelson, G.C., Ahammad, H., Blanc, E., Bodirsky, B., Fujimori, S., Hasegawa, T., Havlik, P., Heyhoe, E., Kyle, P., MasonD’Croz, D., Paltsev, S., Rolinski, S., Tabeau, A., van Meijl, H., von Lampe, M. and Willenbockel, D. (2014). The furure of food demand: understanding differences in global economic models. Agricultural Economics, 45: 51-67.

\section{How to cite this article:}

Mamta Phogat, Rita Dahiya, P. S. Sangwan and Santhosh Kumar, M. 2020. Microbiological Properties of Soils as Affected by Long Term Zero Tillage: A Review. Int.J.Curr.Microbiol.App.Sci. 9(11): 393-400. doi: https://doi.org/10.20546/ijcmas.2020.911.048 